QA: N/A

BECHTEL

SAIC Compaw

MIS-MGR-EC-000001, Rev 0

July 2002

\title{
Environmental Aspects, Objectives and Targets Identification Process
}

By

Environmental, Safety, and Health Assessment and

Environmental Compliance Organizations

Prepared for:

U.S. Department of Energy

Yucca Mountain Site Characterization Office

P.O. Box 30307

North Las Vegas, Nevada 89036-0307

Prepared by:

Bechtel SAIC Company, LLC

1180 Town Center Dr., MS 423

Las Vegas, Nevada 89144

Under Contract Number

DE-AC28-01RW12101 


\section{Disclaimer}

This report was prepared as an account of work sponsored by an agency of the United States Government. Neither the United States Government nor any agency thereof, nor any of their employees, nor any of their contractors, subcontractors or their employees, makes any warranty, express or implied, or assumes any legal liability or responsibility for the accuracy, completeness, or any third party's use or the results of such use of any information, apparatus, product, or process disclosed, or represents that its use would not infringe privately owned rights.

Reference herein to any specific commercial product, process, or service by trade name, trademark, manufacturer, or otherwise, does not necessarily constitute or imply its endorsement, recommendation, or favoring by the United States Government or any agency thereof or its contractors or subcontractors. The views and opinions of authors expressed herein do not necessarily state or reflect those of the United States Government or any agency thereof. 


\section{Environmental Aspects, Objectives, and Targets Identification Process}

Prepared by:

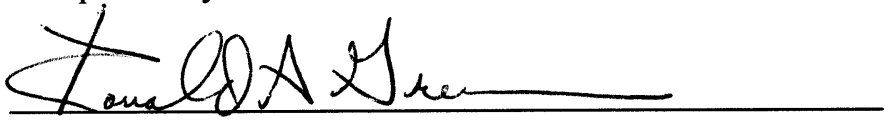

Ronald A. Green, Manager

Environmental Sciences

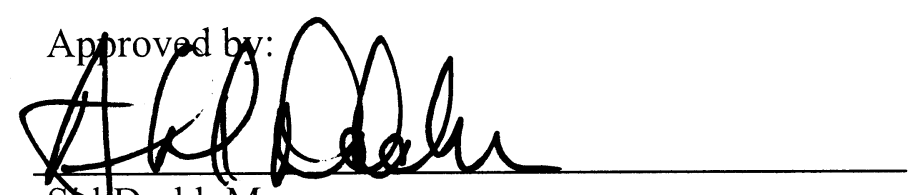

STWDodd, Manager

Environmental, Safety, and Health Assessments

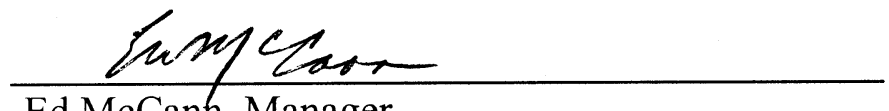

Ed McCann, Manager

Environmental Compliance

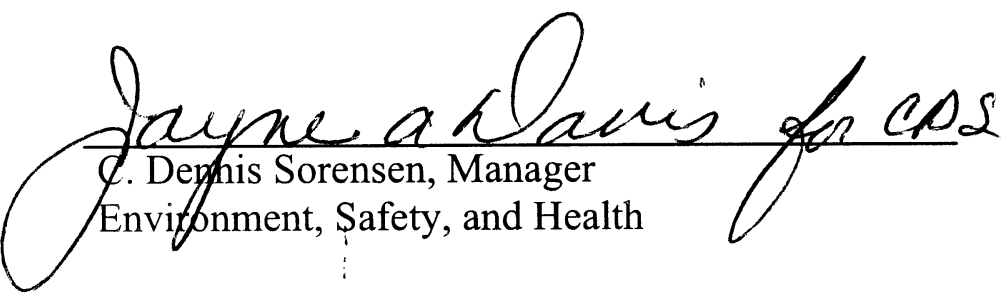

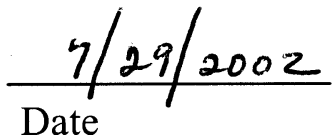
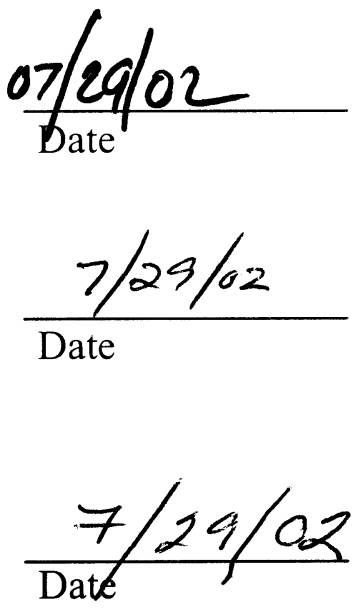


\section{Change History}

$\begin{array}{ccll}\begin{array}{c}\text { Revision } \\ \text { Number }\end{array} & \begin{array}{l}\text { Interim } \\ \text { Change No. }\end{array} & \begin{array}{l}\text { Approval } \\ \text { Date }\end{array} & \begin{array}{l}\text { Description of Change } \\ 0\end{array} \\ 0 & 07 / 29 / 2002 & \text { Initial issue }\end{array}$




\section{CONTENTS}

Page

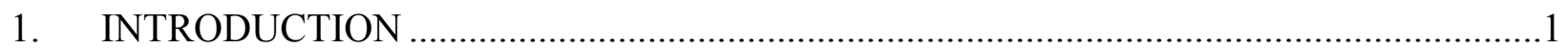

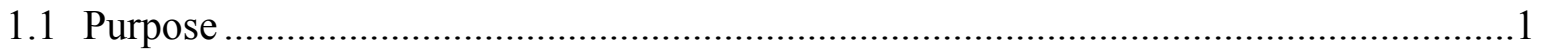

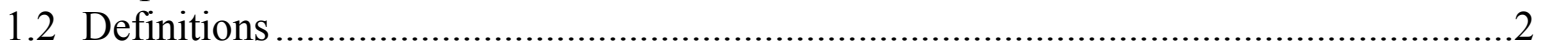

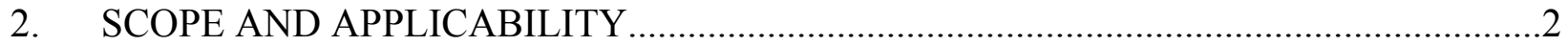

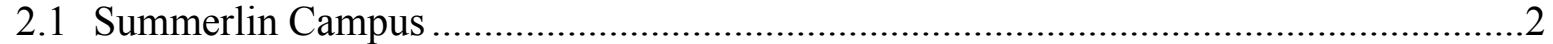

2.2 Yucca Mountain Site Characterization Area _...............................................................2

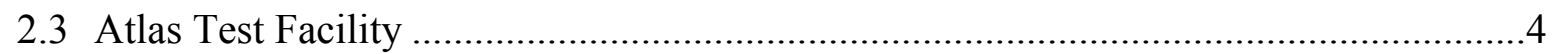

2.3 YMP Science Centers..........................................................................................

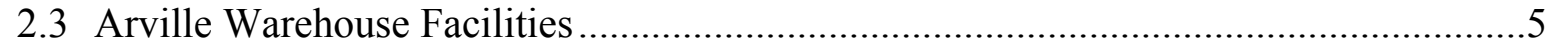

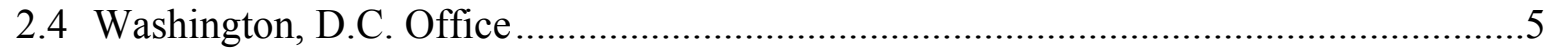

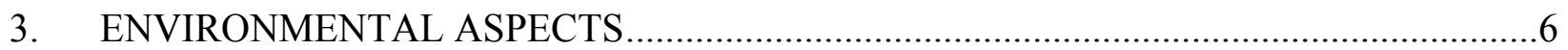

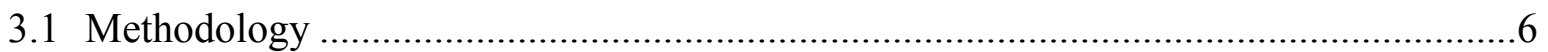

3.2 BSC Work Activities, Products, and Service ...............................................................

3.4 Environmental Aspects..........................................................................................10

4. SIGNIFICANCE OF BSC ENVIRONMENTAL ASPECTS ……...................................1

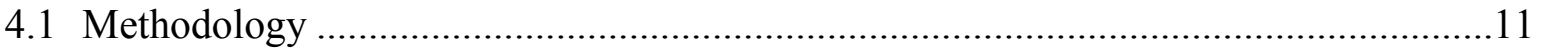

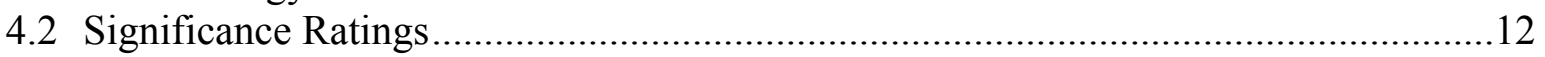

5. ENVIRONMENTAL OBJECTIVES AND TARGETS.........................................................

5.1 Objective \# 1: Reduce and Minimize Project Use of Non-potable Water in Area 25

5.2 Objective \# 2: Reduce and Minimize Project Use of Potable Water

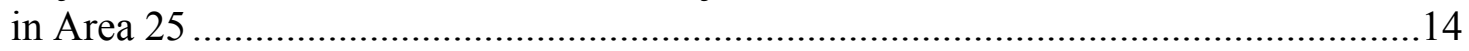

5.3 Objective \# 3: Reduce and Minimize Use of Paper ...................................................15

5.4 Objective \# 4: Have No Notice's of Violation (NOVs) for Any Environmental Permit, State or Federal Law, or Regulation.................................................................16

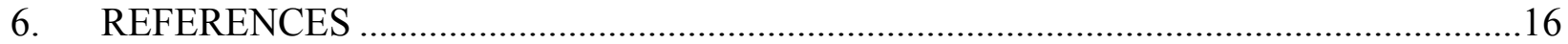

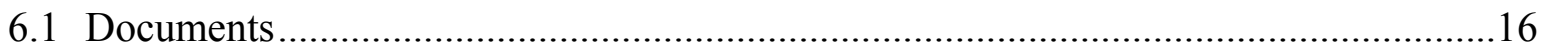

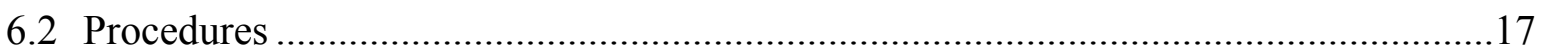

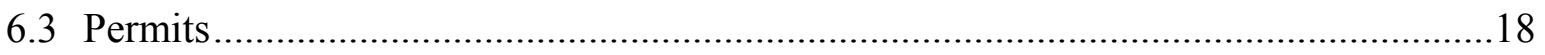

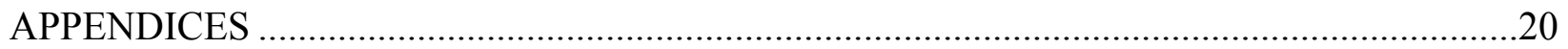

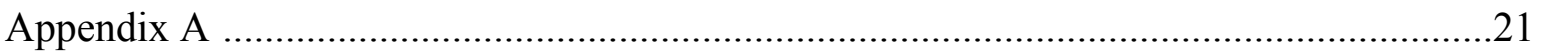

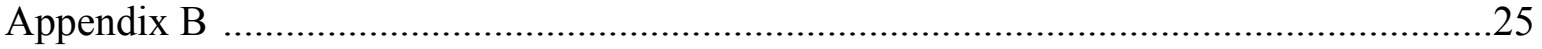

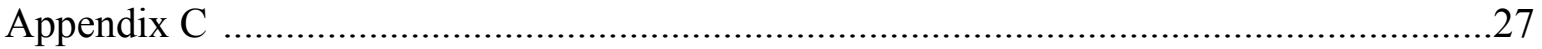




\section{TABLES}

Page

1. BSC Facilities Classified by Facility Type, Location Setting, and Primary Work Activity

2. Description of Bechtel SAIC Company, LLC Work Activities, Products, and Services

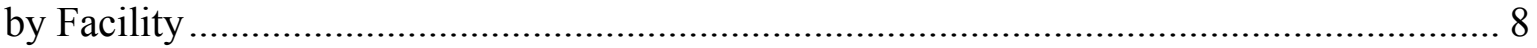

3. Environmental Aspects Associated with BSC Work Activities .......................................... 10

4. Significance Rating of BSC Environmental Aspects Based on Five Rating Criteria .......... 13

A.1. Description of Potential Environmental Impacts Associated with BSC Environmental Aspects

B.1. Description and Definition of Environmental Criteria for Evaluating the Significance of Environmental Aspects of BSC Activities, Products, and Services

B.2. Description and Definition of Safety and Health Criteria for Evaluating the Significance of Environmental Aspects of BSC Activities, Products, and Services

B.3. Description and Definition of Regulatory Compliance Criteria for Evaluating the Significance of Environmental Aspects of BSC Activities, Products, and Services. 25

B.4. Description and Definition of Financial Criteria for Evaluating the Significance of Environmental Aspects of BSC Activities, Products, and Services ................................... 26

B.5. Description and Definition of Business Criteria for Evaluating the Significance of Environmental Aspects of BSC Activities, Products, and Services

C.1. Significance ratings for BSC Environmental Aspects Based on Characteristic of the Potential Environmental Impact .....

C.2. Significance Ratings for BSC Environmental Aspects Based on Safety and Health Factors.

C.3. Significance Ratings for BSC Environmental Aspects Based on Regulatory Compliance Considerations.

C.4. Significance Ratings for BSC Environmental Aspects Based on Financial Considerations 30

C.5. SignificanceRratings for BSC Environmental Aspects Based on Business Operation Factors 


\section{FIGURES}

1. Surface facilities of the Exploratory Studies Facility at Yucca Mountain ..... 3

2. Entrance to the tunnel at the Exploratory Studies Facility at Yucca Mountain.......................3

3. Tunnel at the Exploratory Studies Facility at Yucca Mountain...............................................

4. Atlas Test Facility at the DOE/NNSA North Las Vegas Facility...........................................

5. Yucca Mountain Project Science Center in Las Vegas, Nevada .............................................. 


\section{INTRODUCTION}

Bechtel SAIC Company, LLC (BSC) has implemented an Integrated Safety Management System (reference) to ensure that the work it performs for the Yucca Mountain Site Characterization Project (YMP) under contract to the U. S. Department of Energy (DOE) is conducted in an environmentally responsible manner, safely, and without harm to human health. This is accomplished by defining the scope of work, analyzing the work hazards, implementing hazard controls, and performing the work within those controls. To enhance the ISMS as it relates to environmental issues and concerns, BSC is implementing an Environmental Management System (EMS) based the International EMS standard, ISO 14001. The international standard requires that an organization:

"Identify the environmental aspects of its activities, products or services that it can control and over which it has influence, in order to determine those which have or can have significant impacts on the environment. The organization shall ensure that the aspects related to these significant impacts are considered in setting its environmental objectives."

An environmental aspect is defined as any element of an organization's activities, products or services that can interact with the environment and cause a potential environmental impact, negative or positive. The international EMS standard also requires that an organization determine which environmental aspects may have a significant effect on the environment and that those aspects be considered when establishing environmental objectives and targets.

\subsection{Purpose}

The purpose of this report is to document the environmental aspects and associated environmental impacts of the BSC scope of work, evaluate the significance of those environmental aspects based on established criteria, and establish environmental objectives and targets for specific environmental aspects. This report is intended to be used by environmental staff in the evaluation of BSC work packages during the annual risk-based planning process. This report shall be fully reviewed and revised annually during the annual work planning process to reflect changes in BSC operations, facilities, and scope of work. Planned BSC work will be evaluated to determine if the work is covered by a previously defined activity, product or service (see Table 2); if work activities require redefinition or addition of a new activity; and if the significant evaluation for each environment aspect is still valid based on scope of planned work. New workscope initiated during the fiscal year through the Baseline Change Proposal process (i.e., not as part of the annual work plan) also will be reviewed for new environmental aspects and determination of whether the new workscope would change the significance rating of any environmental aspect. If a new environmental aspect is identified in a new work activity, product, or service but the aspect is not determined to be significant (see Section 4), then this report can be changed through an interim change notice (ICN). This report can be changed five times through an ICN before a full revision is required. However, if new workscope causes an environmental aspect to be graded as significant using the evaluation process in Section 4, this report shall be revised though a full review and revision. 


\subsection{Definitions}

To ensure common usage, the terms listed below and used in this report have the following definitions.

Environment - Surroundings in which an organization operates, including air, water, land, soil, natural resources, cultural resources, flora, fauna, humans, and their interaction.

Environmental Aspect - Any element or process of BSC activities, products or services that interacts with the environment.

Environmental Impact - Any change in the environment, adverse or beneficial, wholly or partially caused by an organization's activities, products or services.

Environmental Medium - Components of the environment with which environmental aspects may interact such as air, water, soil, natural resources, etc.

\section{SCOPE AND APPLICABILITY}

This environmental aspect analysis applies to all work activities, products, and services at Yucca Mountain Site Characterization Project (YMP) sites for which BSC manages the work control process. These sites include the Yucca Mountain site characterization area in Nye County, Nevada; the Summerlin campus occupied by BSC and subcontractors; the Arville warehouse; the Las Vegas, Beatty, and Pahrump Science Centers; North Las Vegas Atlas test facility, and the DC office. Because BSC work is performed at several different locations, a brief description of each facility and the operations performed at each is provided.

\subsection{Summerlin Campus}

The Summerlin Campus is the company headquarters for BSC and is the work location for the majority of BSC employees and subcontractors. The Campus is composed of 14 office buildings in a suburban business park in Las Vegas, Nevada. The buildings contain standard office space (offices, cubicles, conference rooms, etc.). The primary operations include general administrative, management, business and financial, scientific and engineering analyses and modeling, and engineering design functions. The Summerlin Campus contains no science or engineering laboratories. This facility is connected to municipal utility services such as sewer, water, electrical, and telecommunications. BSC pays for the utility services in those buildings except for three multi-tenant buildings $(13,14 \mathrm{~A} / \mathrm{B}$, and 15) where the lessor pays for the utilities. The Summerlin office buildings are leased and the owners are responsible for maintaining the buildings and ensuring that they continue to meet all applicable codes and standards.

\subsection{Yucca Mountain Site Characterization Area}

Characterizing and evaluating the suitability of Yucca Mountain as a potential geologic repository for high-level nuclear waste is the primary mission of BSC work for DOE. Yucca Mountain is located in a remote desert environment 90 miles northwest of Las Vegas on the southwest corner of the Nevada Test Site (Area 25) and adjacent public lands and is the site for 
most scientific and engineering tests being performed by BSC and subcontractors. The primary facilities at Yucca Mountain include the Exploratory Studies Facility (ESF), equipment storage yards, and a Sample Management Facility (SMF). The ESF is composed of surface buildings, shops, and warehouses (Figure 2); and a 5 mile, 24 foot diameter, tunnel that loops through Yucca Mountain (Figure 3 and 4). The primary operation is surface and subsurface scientific and engineering field tests and experiments to characterize and evaluate the site as a potential geologic repository for high-level nuclear waste. An extensive construction operation is present to build, maintain, and operate the infrastructure necessary to support the field-testing. Because these facilities are located in a remote desert area, BSC and previous DOE contractors constructed the facilities and infrastructure including sewage, power, water, roads, and communication systems. A more complete description of the facilities located near Yucca Mountain is found in the Safety Basis Report, TDR-CRW-SE-000008.
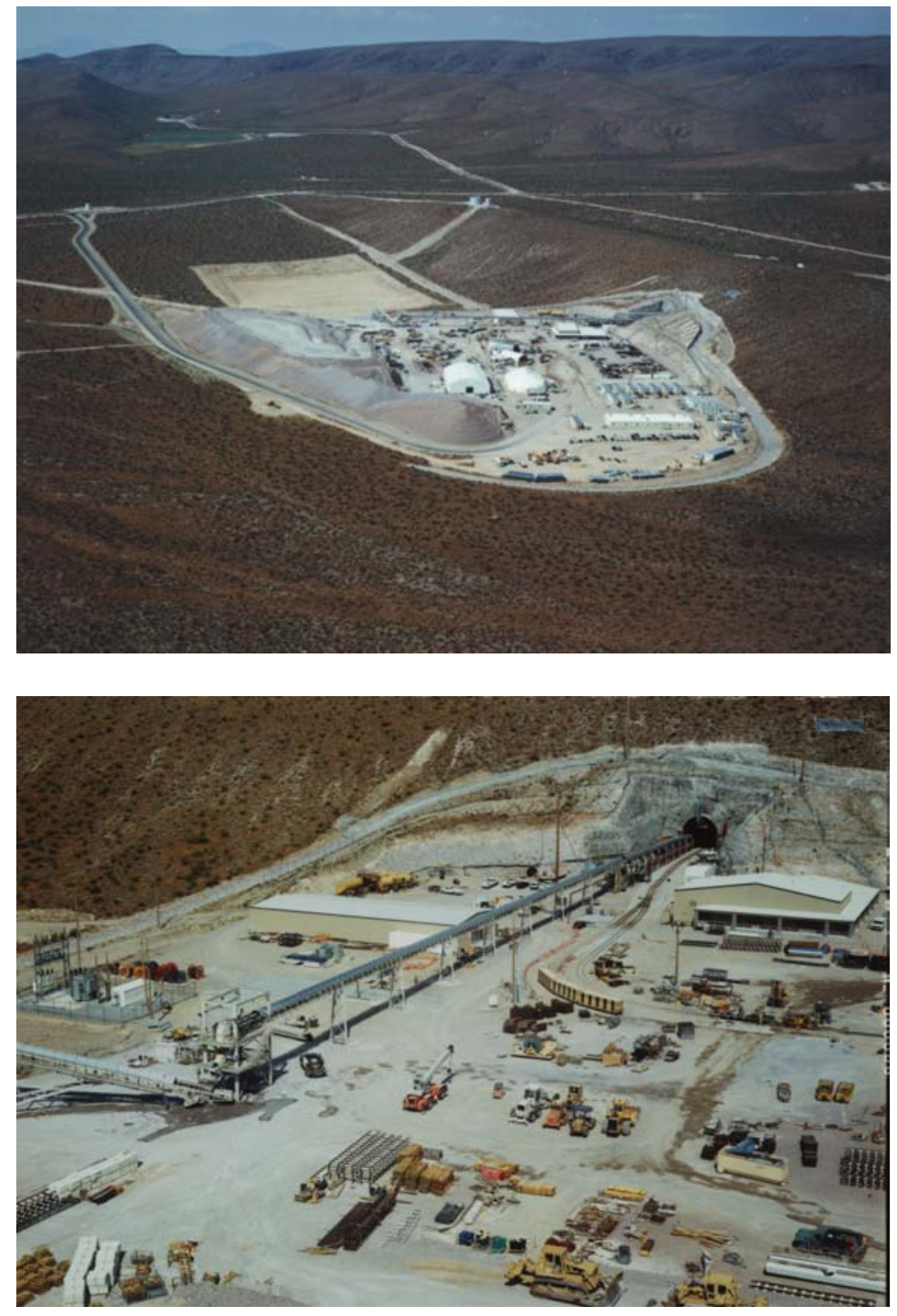

Figure 1. Surface Facilities of the Exploratory Studies Facility at Yucca Mountain
Figure 2. Entrance to the Tunnel at the Exploratory Studies Facility at Yucca Mountain 


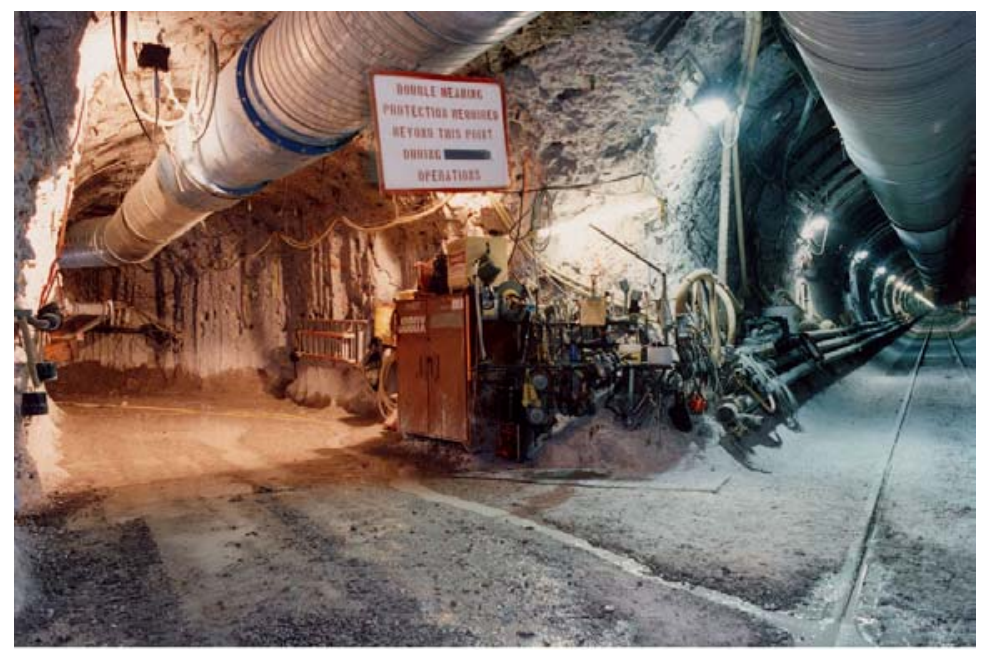

YM-20403 VIEW OF THE INTERSECTION OF ALCOVE\# AND THE ECRB.
Figure 3. Tunnel at the Exploratory Studies Facility at Yucca Mountain

\subsection{Atlas Test Facility}

The Atlas Test Facility is a laboratory testing facility located in an industrial and warehouse area in the city of North Las Vegas. The facility consists of two buildings (known as the "Atlas" facilities) within the DOE Nevada Nuclear Security Agency operation complex. The buildings are leased and permitted through DOE from Bechtel Nevada, the managing and operating contractor for the facility. The facilities are built and maintained according to state and local codes and regulations. Any modifications to infrastructure or facility conditions are made through the Bechtel Nevada contract.

These buildings are used to conduct tests for studies of the Engineered Barrier and Waste Package systems that may be used at Yucca Mountain (Figure 5). Studies being conducted include tests of soil properties, small-scale thermal-hydrological-chemical test, scaled thermal tests on various drip shield and backfill concepts, and a $40-\mathrm{m}$ long thermal/ventilation experiment.

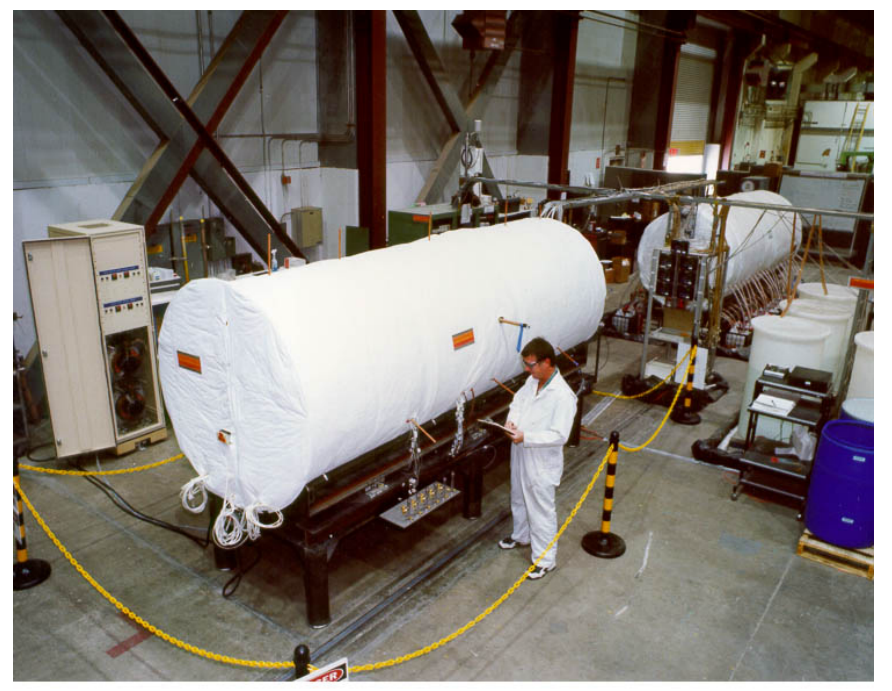

YM-19413 START-UP OF EBS TEST CELL3, ATLAS FACILITY
Figure 4. Atlas Test Facility at the DOE/NNSA North Las Vegas Facility 


\subsection{YMP Science Centers}

The YMP leases office buildings in Las Vegas, Pahrump, and Beatty, Nevada, for use as Science Centers to provide project information to the public. The Science Centers have information displays that describe the project for the public. These facilities are connected to municipal utility services for sewer, water, electrical, and telecommunications. BSC pays for the utility services in these building. The building owners are responsible for maintaining the buildings and ensuring that they continue to meet all applicable codes and standards.

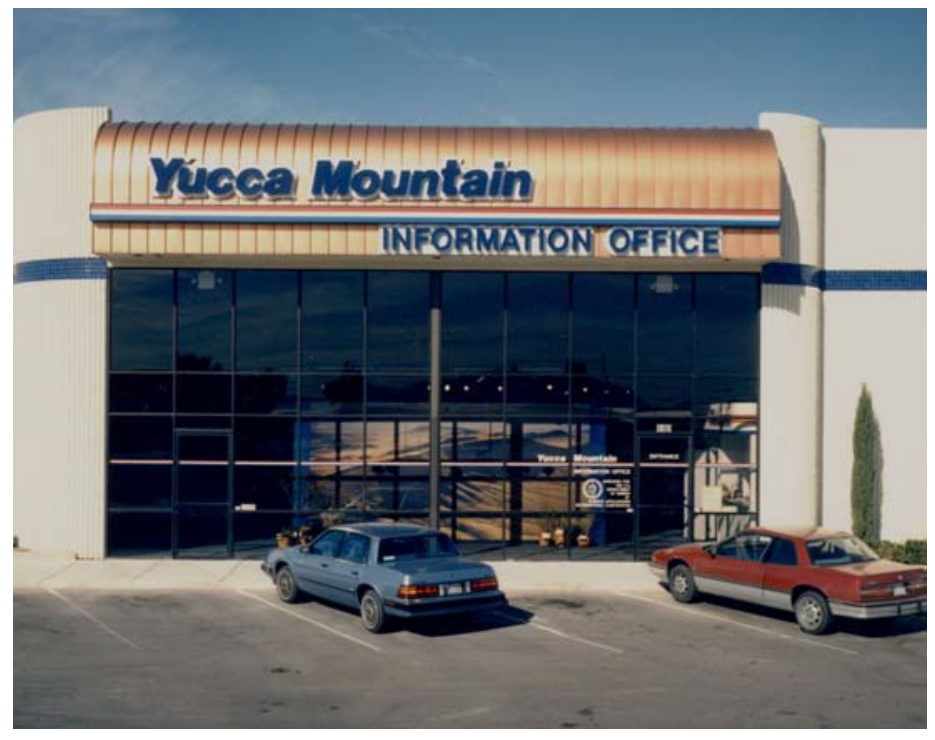

Figure 5. Yucca Mountain Project

Science Center in Las Vegas, Nevada

\subsection{Arville Warehouse Facilities}

BSC operates a warehouse (on Arville St.) in Las Vegas for shipping and receiving purchased equipment and supplies as well as to store computer equipment and office furnishings. BSC currently has a short-term lease on a second warehouse (referred to as Wesco) on Sheridan Street near the Arville Warehouse and leased from the same company. Both buildings are located in a commercial warehouse area and are connected to municipal utility services for sewer, water, electrical, and telecommunications. BSC pays for the utility services in both warehouses. The warehouse facilities are leased, and the warehouse owner is responsible for ensuring that the warehouse continues to meet all applicable building codes and standards.

\subsection{Washington, D.C. Office}

In addition to the primary office buildings located in the Summerlin Complex, BSC also occupies office facilities on the East Coast in Washington, D.C. and in McLean, Virginia. However, the L'Enfant Office located at 955 N. L'Enfant Plaza, SW in Washington, D.C. is the only East Coast facility included under the BSC EMS. The McLean, VA facility is a SAIC facility where BSC has approximately 15 computer support employees housed. Because BSC is not a primary tenant or occupant of this building, it is excluded from the BSC EMS. The L'Enfant Office facility contains standard office space that is used for administrative, management, and technical work. All work is performed in a standard office environment. 
There are no laboratories or warehouse facilities. The building is connected to municipal utility services for sewer, water, electrical, and telecommunications. This facility is leased, and the owner is responsible for ensuring that the building continues to meet all applicable building codes and standards.

\section{ENVIRONMENTAL ASPECTS}

\subsection{Methodology}

BSC facilities were categorized by facility type, location setting, and type of work performed (Table 1). Similar types of facilities were expected to have common characteristics and house similar types of work activities that could be grouped together for the purpose of identifying environmental aspects. Location setting is important because it defines the environment with which BSC activities, products, and services interact and therefore the potential environmental impacts that might occur. The facilities in urban settings exist in environments highly modified by human activity and are connected to municipal utility services and infrastructure opposed to remote locations such as Yucca Mountain. The type of primary work performed at each facility was then considered to help define any broad grouping of BSC activities, products, or services that could simplify the identification of environmental aspects.

The BSC organization structure was then used as a guide to identify specific job activities at each facility location that might have unique environmental aspects. Personal interviews were used as needed to gather additional information concerning work activities in specific organizations or locations. The level of detail in defining work activities was based on professional judgement, interviews, and peer review. An attempt was made to balance defining work activities too narrowly or too broadly. Products and services were then defined for each activity. Environmental aspects were then identified using input/output analyses to identify interactions between work activities, products, and services and environmental media. Environmental media considered include air, soil, land, flora, fauna, cultural resources, natural resources, aesthetics, rock, water, groundwater, and rock.

\subsection{BSC Work Activities, Products, and Service}

BSC performs work in 4 types of facilities: standard office buildings, an industrial laboratory, a warehouse, and a remote field-testing site. These facilities are located in two types of environmental settings: urban and a remote desert location (Table 1). Three types of primary work activities are performed in these facilities: 1) administration, management, and science and engineering analyses, 2) science and engineering testing, and 3) warehouse storage and material handling. 
Table 1. BSC Facilities Classified by Facility Type, Location Setting, and Primary Work Activity

\begin{tabular}{|l|l|l|l|l|}
\hline Facility Name & Abbreviation & Facility Type & $\begin{array}{l}\text { Location } \\
\text { Setting }\end{array}$ & Primary Work Activities \\
\hline Summerlin (14) & LV & Office building & Urban & $\begin{array}{l}\text { Administrative; management; and } \\
\text { science and engineering } \\
\text { analyses, modeling, and design }\end{array}$ \\
\hline $\begin{array}{l}\text { Science Centers (3) } \\
\text { Washington DC } \\
\text { Office }\end{array}$ & SC & Office Building & Urban & $\begin{array}{l}\text { Administrative, management, } \\
\text { education }\end{array}$ \\
\hline Atlas Test Facility & Atlas & Office Building & Urban & $\begin{array}{l}\text { administrative, management, } \\
\text { technical analyses }\end{array}$ \\
\hline $\begin{array}{l}\text { Arville Warehouse } \\
\text { Facilities (2) }\end{array}$ & AW & Waboratory & Urban industrial & Science and engineering testing \\
\hline & & $\begin{array}{l}\text { Science \& } \\
\text { Engineering } \\
\text { field test site }\end{array}$ & Urban industrial & $\begin{array}{l}\text { Receipt, storage, and distribution } \\
\text { of equipment and materials }\end{array}$ \\
Yucca Mountain & YM & $\begin{array}{l}\text { Science \& engineering testing, } \\
\text { construction, equipment operation } \\
\text { and maintenance, tunnel } \\
\text { operation and maintenance }\end{array}$ \\
\hline
\end{tabular}

Thirteen work activities were defined using these categories as guides. Similarity in facility type, environmental setting, and type of work among several of the BSC facilities suggested that the environmental aspects and impacts should be the same regardless of location or facility. Much of the work performed in the Summerlin campus, the three Science Centers, and the Washington, DC office was captured under the single activity titled "Science, Engineering, and Administration \& Management Support" (Table 2). The products produced from this activity consist of data, documents, and information in digital, hardcopy, and verbal format. Additional work activities in these office environments were defined through a review of BSC's organizational structure. Several organizations were identified that could either potentially have unique environmental aspects or have activities and products that disproportionately contributed to a particular environmental aspect. These activities include motorpool operations, office facility operations and maintenance, property and materials management, information technology operations and maintenance, and graphics and reproduction (Table 2).

The Yucca Mountain Site Characterization Area is unique among BSC facilities in that it is located in a remote desert location where providing utilities and other basic infrastructure such as roads and buildings are part of the work activity. Work activities performed at these facilities are different because of the surrounding work environment, even though the products and services are similar in many aspects (Table 2). The primary work activity at Yucca Mountain is conducting science (e.g., geology and hydrology) and engineering tests to characterize the site as a potential geologic repository of high-level nuclear waste. However, to perform those tests requires numerous supporting work activities such as industrial construction; industrial facility operation and maintenance; heavy equipment operation; and regulatory required activities such as environmental sampling and monitoring, land reclamation, and waste (hazardous and nonhazardous) management. 
Table 2. Description of Bechtel SAIC Company, LLC Work Activities, Products, and Services by Facility

\begin{tabular}{|c|c|c|c|c|}
\hline & Activity & Facility & Product/Service & Description \\
\hline 1. & $\begin{array}{l}\text { Science, Engineering, } \\
\text { and Administrative \& } \\
\text { Management Support }\end{array}$ & $\begin{array}{l}\text { Summerlin Campus, } \\
\text { Science Centers, } \\
\text { Washington, DC office }\end{array}$ & $\begin{array}{l}\text { Data, documents, and } \\
\text { information in digital, } \\
\text { hardcopy, and verbal } \\
\text { formats }\end{array}$ & $\begin{array}{l}\text { This activity covers the variety of work performed in BSC office facilities in Las } \\
\text { Vegas and DC. This includes the scientific and engineering analyses and } \\
\text { modeling studies that support the evaluation of Yucca Mountain as a potential } \\
\text { repository of nuclear waste. It also includes the many administrative and } \\
\text { management tasks that are necessary to manage and operate this project for } \\
\text { DOE. The work is performed in a typical office or cubicle setting using standard } \\
\text { desktop communication and computing equipment. The primary product produced } \\
\text { from this work is documentation in the form of digital databases, correspondences } \\
\text { (letters and memos), scientific and engineering reports, training materials, and } \\
\text { administrative records. }\end{array}$ \\
\hline 2. & Motorpool Operation & $\begin{array}{l}\text { Summerlin Campus \& } \\
\text { Yucca Mountain }\end{array}$ & $\begin{array}{l}\text { GSA vehicles for } \\
\text { commuting to work } \\
\text { locations }\end{array}$ & $\begin{array}{l}\text { Fleet Services operates and maintains a pool GSA vehicles in Las Vegas and in } \\
\text { Area } 25 \text { to support BSC work. }\end{array}$ \\
\hline 3. & $\begin{array}{l}\text { Office Facility Operation } \\
\text { \& Maintenance }\end{array}$ & $\begin{array}{l}\text { Summerlin Campus, } \\
\text { Science Centers, DC } \\
\text { office, Arville } \\
\text { Warehouse }\end{array}$ & $\begin{array}{l}\text { Provide facilities for use } \\
\text { by BSC employees \& } \\
\text { contractors }\end{array}$ & $\begin{array}{l}\text { BSC leases and operates facilities in Las Vegas to perform its contracted work for } \\
\text { the Department of Energy. These facilities include a complex of business offices } \\
\text { in Summerlin, a Science Center, a warehouse, and a testing lab in the } \\
\text { DOE/NNSA complex in North Las Vegas. Also provide mail and warehouse } \\
\text { services. }\end{array}$ \\
\hline 4. & $\begin{array}{l}\text { Property \& Materials } \\
\text { Management and } \\
\text { Operations }\end{array}$ & All & $\begin{array}{l}\text { Procurement services, } \\
\text { property management } \\
\text { services }\end{array}$ & $\begin{array}{l}\text { BSC procures and manages government property to perform its contractual work } \\
\text { scope. }\end{array}$ \\
\hline 5. & $\begin{array}{l}\text { Information Technology } \\
\text { Operations, } \\
\text { Management, \& } \\
\text { Maintenance }\end{array}$ & All & $\begin{array}{l}\text { Operable network } \\
\text { servers, desktop PCs, } \\
\text { printers }\end{array}$ & $\begin{array}{l}\text { BSC work requires heavy use of information technology. BSC operates and } \\
\text { maintains a computer network, servers, 1000+ desktop PCs, a network e-mail } \\
\text { and database system (Lotus Notes). }\end{array}$ \\
\hline 6. & $\begin{array}{l}\text { Graphics and } \\
\text { Reproduction }\end{array}$ & $\begin{array}{l}\text { Summerlin Campus, DC } \\
\text { office }\end{array}$ & $\begin{array}{l}\text { Graphics, technical and } \\
\text { management } \\
\text { documents }\end{array}$ & $\begin{array}{l}\text { A primary activity and product of BSC is developing and producing information in } \\
\text { the form of data, documents, and graphics. BSC operates a graphic and } \\
\text { reproduction center on the Summerlin campus and in the DC office to prepare } \\
\text { and produce graphics \& documentation as needed to meet project requirements. }\end{array}$ \\
\hline 7. & $\begin{array}{l}\text { Scientific \& Engineering } \\
\text { Testing }\end{array}$ & $\begin{array}{l}\text { Yucca Mountain, Atlas } \\
\text { Test Facility }\end{array}$ & $\begin{array}{l}\text { Scientific and } \\
\text { engineering data }\end{array}$ & $\begin{array}{l}\text { BSC conducts a variety of field and laboratory investigations regarding the } \\
\text { geology, hydrology, and engineering properties of Yucca Mountain and vicinity. } \\
\text { These investigations occur primarily at Yucca Mountain (i.e., field studies). } \\
\text { However, several laboratory based studies are conducted in the Atlas Test } \\
\text { Facility. Field studies are either conducted via surface-based tests (boreholes, } \\
\text { trenches, etc.) or in the exploratory tunnel through Yucca Mountain. The data } \\
\text { gathered from these investigations provide input into the scientific and } \\
\text { engineering analyses and modeling being performed in the Summerlin offices } \\
\text { (see Activity \# 1). }\end{array}$ \\
\hline
\end{tabular}


Table 2. Description of Bechtel SAIC Company, LLC Work Activities, Products, and Services by Facility

\begin{tabular}{|c|c|c|c|c|}
\hline & Activity & Facility & Product/Service & Description \\
\hline 8. & $\begin{array}{l}\text { Area } 25 \text { Surface Facility } \\
\text { Operations, } \\
\text { Maintenance, \& } \\
\text { Construction }\end{array}$ & Yucca Mountain & $\begin{array}{l}\text { Provide facilities and } \\
\text { infrastructure to support } \\
\text { science and } \\
\text { engineering test studies }\end{array}$ & $\begin{array}{l}\text { BSC and previous project contractors have constructed a number of surface } \\
\text { facilities, which BSC now operates and maintains. BSC will construct additional } \\
\text { facilities as project needs require. Surface facilities include but are not limited to } \\
\text { the ESF North and South Portal pad areas, several laydown yards, borrow pits, } \\
\text { and a network of roads. The North Portal pad is the primary surface operation } \\
\text { and consists of office trailers, a variety of machine shops and equipment } \\
\text { maintenance areas, and storage areas. Because of the remote location much of } \\
\text { the utility infrastructure (e.g., water distribution system, electric power system, } \\
\text { sanitary sewer system, \& roads) has been constructed and is operated and } \\
\text { maintained by BSC. }\end{array}$ \\
\hline 9. & $\begin{array}{l}\text { ESF Tunnel } \\
\text { Construction, } \\
\text { Operation, and } \\
\text { Maintenance }\end{array}$ & Yucca Mountain & $\begin{array}{l}\text { Provide a tunnel } \\
\text { accessible for science \& } \\
\text { engineering studies and } \\
\text { construction support to } \\
\text { those studies }\end{array}$ & $\begin{array}{l}\text { A major part of the Area } 25 \text { operations is the exploratory tunnel ( } 24 \text { foot diameter) } \\
\text { that loops approximately } 5 \text { miles through the mountain and a cross-drift tunnel ( } 12 \\
\text { feet diameter) that penetrates the potential repository rock strata. The tunnel } \\
\text { complex is the location of many major scientific and engineering studies and has } \\
\text { rail, electric power, ventilation system, and communication systems. }\end{array}$ \\
\hline 10. & $\begin{array}{l}\text { Area } 25 \text { Equipment } \\
\text { Operation \& } \\
\text { Maintenance }\end{array}$ & Yucca Mountain & $\begin{array}{l}\text { Equipment to support } \\
\text { science and } \\
\text { engineering test } \\
\text { activities }\end{array}$ & $\begin{array}{l}\text { BSC operates and maintains a variety of heavy equipment for earth moving, } \\
\text { grading roads, rigs for drilling boreholes, excavating trenches, and hauling water } \\
\text { to support the science and engineering studies being conducted at Yucca } \\
\text { Mountain and to assist in the development and construction of facilities. BSC } \\
\text { operates a train system for transportation in the tunnel, a variety of mining } \\
\text { equipment for hard rock drilling and excavation, and diesel generators for auxiliary } \\
\text { power sources. }\end{array}$ \\
\hline 11. & $\begin{array}{l}\text { Environmental Media } \\
\text { Sampling \& Monitoring }\end{array}$ & Yucca Mountain & $\begin{array}{l}\text { Environmental } \\
\text { monitoring data }\end{array}$ & $\begin{array}{l}\text { BSC conducts a variety of environmental media sampling and monitoring to } \\
\text { comply with numerous environmental requirements established through state, } \\
\text { federal laws and regulations or permits issued under such laws and regulations. } \\
\text { For example, BSC operates and maintains air quality/meteorological monitoring } \\
\text { stations. }\end{array}$ \\
\hline 12. & Land Reclamation & Yucca Mountain & Revegetated land & $\begin{array}{l}\text { BSC reclaims previously disturbed sites no longer needed for site characterization } \\
\text { with native vegetation to comply with the Endangered Species Act, the Nuclear } \\
\text { Waste Policy Act, Invasive Species Executive Order. }\end{array}$ \\
\hline 13. & Waste Management & All & $\begin{array}{l}\text { Properly disposed } \\
\text { waste }\end{array}$ & $\begin{array}{l}\text { To comply with various regulations regarding hazardous and non-hazardous } \\
\text { waste, BSC has a waste management program, including several waste } \\
\text { accumulation areas. }\end{array}$ \\
\hline
\end{tabular}




\subsection{Environmental Aspects}

Twenty-two environmental aspects were identified for current BSC work activities (Table 3). Several environmental aspects were associated with almost all work activities. These included electricity use, paper use, potable water use, and petroleum product use. These aspects represent basic inputs into all work performed by BSC. As expected work activities at the Yucca Mountain Site Characterization Area had more environmental aspects then work performed in office buildings in urban environments.

Potential environmental impacts associated with BSC's environmental aspects are discussed in Appendix A (Table A.1).

Table 3. Environmental Aspects Associated with BSC Work Activities

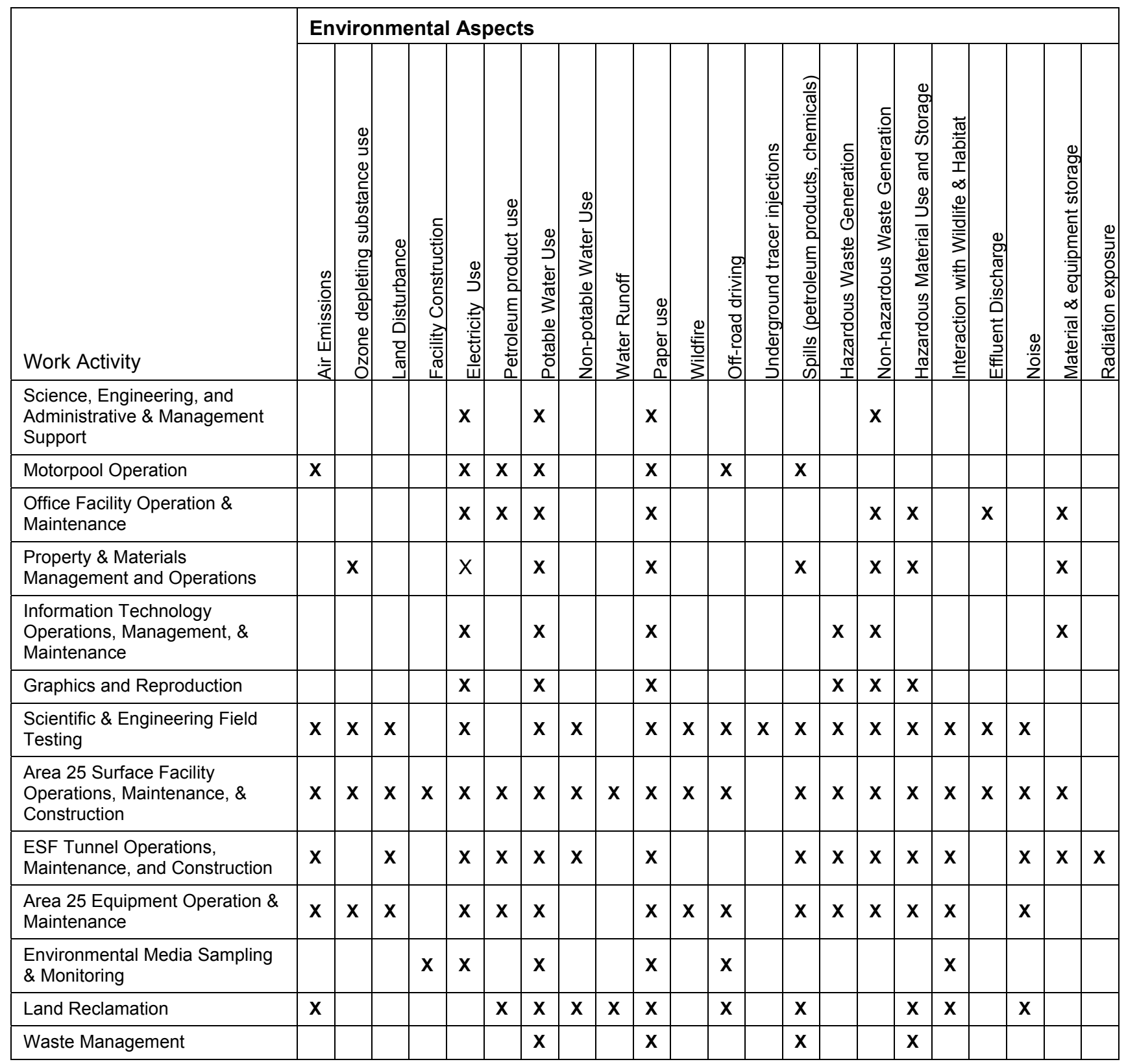




\section{SIGNIFICANCE OF BSC ENVIRONMENTAL ASPECTS}

\subsection{Methodology}

Environment aspects of BSC activities, products, and services were evaluated for importance based on five criteria: environmental, safety and health, regulatory compliance, financial, and business. For each criterion, the environmental aspect was rated into one of three categories: high, medium, and low. A significant environmental aspect is defined as any aspect rated in the "High" category.

The environmental criterion considers potential impacts on air, soil, flora, fauna, renewable natural resources such as paper, and non-renewable natural resources such as energy sources (coal, gas, nuclear). Four impact characteristics were considered for environmental impacts: scale, severity, frequency of occurrence, and duration (Appendix B, Table B.1). Scale accounts for the size or extent of an environmental impact while severity is a measure of intensity or longevity of the impact. Frequency of occurrence is how often an impact might be expected to occur, and duration is how long an impact might remain taking into account any reasonable and practicable remediation effort.

The safety and health criterion assesses the impact of environmental aspects on BSC employees, subcontractors, and the general public through injuries or changes in health condition. The criterion considers the severity of a potential injury or change in health condition that might result from or be caused by an environmental aspect (Appendix B, Table B.2).

The regulatory compliance criterion addresses regulatory oversight of environmental aspects as it relates to potential Notices of Violations (NOVs), fines, or other penalties and the extent of regulatory agency scrutiny (Appendix B, Table B.3).

The financial criterion considers the potential cost of an environmental aspect to the company. It considers two types of cost (Appendix B, Table B.4). The first type is simply the cost to the company for having an environmental aspect as part of its business operation. Examples might include the cost of electricity to operate a facility or the cost of purchasing paper to produce documents. The second type of cost is potential cost for remedial action, repair or replacement of equipment and facilities, or rehabilitation or loss work time for employees.

The business criterion considers the influence of environmental aspects on the ability of BSC to conduct their business operations. It considers how an environmental aspect may impact a particular job function, an entire business unit or operation, and the public image of the company (Appendix B, Table B.5). Impacts on job functions and business units are defined in terms of interruptions to work and how long the interruption lasts. The public image factor considers whether the public is interested in a particular environmental aspect and whether it might be newsworthy, negative or positive.

To determine whether an environmental aspect was significant, the rating or judging process was kept relatively simple. No scoring system (i.e., where points are assigned the high, medium, or low categories) or scoring algorithm (i.e., adding points together for an index score) was used. It was felt that such an approach was unnecessarily complicated and may actually make the decision process more difficult. Each environmental aspect was first rated into the High, 
Medium, and Low categories using the information in Appendix B, Tables B.1-5 for each factor or characteristic within the five rating criteria based on company data or professional judgement (Appendix C, Tables C.1-5). The ratings for each criterion factor were then combined into an overall rating for that criterion based on professional judgement of which were the most important factors. For example, "Air Emissions" under the Environmental criterion could be rated "Low" for scale, severity, and duration but "High" for probability of occurrence. However, the overall rating for "Air Emissions" for the environmental criterion would likely be "Low" because the scale, severity, and duration factors would be considered more important.

The overall significance rating for each environmental aspect was then determined by evaluating together the significance ratings assigned to each environmental aspect for each of the five rating criterion (right-hand columns of Appendix C, Tables C.1-5). The overall rating for each environmental aspect was determined by judging the relative importance of each of the five criteria. For example, if "Non-potable Water Use" was rated "High" under the business criterion because of the potential to stop work at the site because of no water, this criterion would likely override all other criteria, regardless of their ratings.

\subsection{Significance Ratings}

Three of the 22 BSC environmental aspects were rated as significant (Table 4, right-hand column). Both Potable and Non-potable water use at Yucca Mountain were rated as significant environmental aspects because for regulatory and business reasons (Tables 4, C.3, and C.5). Because of legal issues regarding water appropriation permits, effective April 9. 2002, YMP no longer can pump water from Wells J-12 and J-13 that supply both potable and non-potable water to operations at Yucca Mountain. YMP has stored 50,000 gallons of potable and 1 million gallons of non-potable water to use while the water issues are resolved in the judicial courts. Water conservation is critical to keeping facilities and science and engineering testing operational.

In fiscal year 2001, BSC made over 15 million copies in the course of performing its workscope. This represents a significant financial operation cost (i.e., over $\$ 100,000$ ) that could be reduced. It also represents a significant use of natural resources (producing paper) and also produces a considerable waste stream that must be managed (even if the paper is recycled). 
Table 4. Significance Rating of BSC Environmental Aspects Based on Five Rating Criteria

\begin{tabular}{|c|c|c|c|c|c|c|}
\hline \multirow[b]{2}{*}{ Environmental Aspect } & \multicolumn{6}{|c|}{ Significance Ranking } \\
\hline & Environmental & $\begin{array}{c}\text { Safety \& } \\
\text { Health }\end{array}$ & $\begin{array}{l}\text { Regulatory } \\
\text { Compliance }\end{array}$ & Financial & Business & $\begin{array}{c}\text { Overall } \\
\text { Ranking }\end{array}$ \\
\hline Air Emissions & Low & Low & Medium & Low & Medium & Medium \\
\hline Ozone depleting substance use & Low & Low & Low & Low & Low & Low \\
\hline Land Disturbance & High & Low & Low & High & Low & Medium \\
\hline Facility Construction & Low & Low & Low & Low & Low & Low \\
\hline Electricity Use & Low & Low & Low & Medium & Medium & Medium \\
\hline Petroleum product use & Low & Low & Low & Medium & Low & Low \\
\hline Potable Water Use & Low & Low & High & Medium & High & High \\
\hline Non-potable Water Use & Low & Low & High & Medium & High & High \\
\hline Water Runoff & Low & Low & Low & Low & Low & Low \\
\hline Paper use & Medium & Low & Low & High & Low & High \\
\hline Wildfire & Medium & Medium & Low & Medium & Medium & Medium \\
\hline Off-road driving & Medium & Low & Low & Low & Low & Low \\
\hline Underground tracer injections & Low & Low & Medium & Low & Medium & Medium \\
\hline Spills (petroleum products, chemicals) & Low & Low & Medium & Medium & Medium & Medium \\
\hline Hazardous Waste Generation & Low & Low & Medium & Medium & Low & Low \\
\hline Non-hazardous Waste Generation & Low & Low & Low & Low & Low & Low \\
\hline $\begin{array}{l}\text { Hazardous Material Use, Storage, \& } \\
\text { Transportation }\end{array}$ & Low & Low & Medium & Low & Medium & Low \\
\hline Interaction with Wildlife \& Habitat & Low & Low & Low & Low & Low & Low \\
\hline Effluent Discharge & Low & Low & Medium & Low & Low & Low \\
\hline Noise & Low & Low & Low & Low & Low & Low \\
\hline Material \& equipment storage & Low & Low & Low & Medium & Low & Low \\
\hline Radiation exposure & Low & Medium & Low & Low & Medium & Medium \\
\hline
\end{tabular}




\section{ENVIRONMENTAL OBJECTIVES AND TARGETS}

Four environmental objectives and targets have been established to improve and maintain BSC environmental performance on the Yucca Mountain Site Characterization Project. Objectives and targets were based on the evaluation of environmental aspects (Table 4) associated with BSC work activities, products, and services. Environmental management programs or actions plans are required for all BSC environmental objectives to ensure that targets are met. The environmental management programs for each are briefly summarized following each objective and target in the following sections. However, the details are contained in the various plans, procedures, standing orders, policies, or management directives that compose the management program for each objective and target.

\subsection{Objective \# 1: Reduce and Minimize Project Use of Non-potable Water in Area 25}

BSC has established an objective to reduce and minimize use of non-potable water at Yucca Mountain for all facilities and work activities that are supported by non-potable water pumped from Wells J-12 and J-13 and stored prior to April 9, 2002.

Background: On April 9, 2002, YMP water appropriation permits from the State of Nevada for Wells J-12 and J-13 expired. The State refused to renew the permits based on the grounds that the original permits were only for support to the characterization of Yucca Mountain as a potential repository of nuclear waste. Because Yucca Mountain was formally recommended to the President and Congress for development of a repository in January 2002, the State contends that site characterization is complete and therefore water is no longer needed for characterization activities. Water appropriation for use in repository construction and operation has not been granted yet. To allow work activities at Yucca Mountain to continue, the project procured an aboveground storage reservoir to hold one million-gallons of non-potable water for use after April 9. This reservoir was filled prior to the expiration of the appropriation permits. Without non-potable water, many work activities would cease. Non-potable water primarily is used for dust control to ensure compliance with the project's air quality operating permit; fire suppression; ESF tunnel science and engineering tests; and for surface-based tests that use tracer injections. The minimization of non-potable water use is intended to keep Area 25 activities going until the water appropriations issue is resolved in the Judicial court system.

Management Program: A dust control and water conservation plan has been established and implemented through Standing Order SO-2002-01. This plan establishes specific processes and rules for conducting work that requires non-potable water. All water use is approved through central authority in the Project Field Engineer office in Area 25. Water use is metered, logged, and tracked.

\subsection{Objective \# 2: Reduce and Minimize Project Use of Potable Water in Area 25}

BSC has established an objective to reduce and minimize use of potable water at Yucca Mountain for all facilities and work activities that are supported by water pumped and stored from Wells J-12 and J-13 prior to April 9, 2002, and is treated in the public water system.

Background: The background issues regarding the need to conserve potable water is the same as that previously described under the non-potable water conservation goal. Potable water 
primarily is used for the Sanitary Sewer System. This system handles water from showers and restrooms. Although this water is of drinking quality, most water for drinking is delivered through purchased bottled water. Potable water is treated and stored in an aboveground storage tank on Exile Hill above the ESF North Portal Pad. This tank was filled prior to the expiration of the water appropriation permit on April 9, 2002. This tank holds 50,000 gallons.

Management Program: A dust control and water conservation plan has been established and implemented through Standing Order SO-2002-01. The SO states that all drinking water will be provided by bottled water. Although employees are encouraged to minimize potable water use, no additional measures or restrictions have been implemented. To ensure that potable water quality standards are maintained, the frequency with which water samples are collected and analyzed has been increased to approximately once per week. Potable water use is metered, logged, and tracked.

\subsection{Objective \# 3: Reduce and Minimize Use of Paper}

Effective August 2001, the BSC President and General Manager established the goal to reduce paper use by BSC. A target of 50 percent reduction was set.

Background: BSC's Environmental Management Policy states that pollution prevention will be integrated into project planning and activities to reduce waste generated, to conserve natural resources and energy, and to minimize environmental impacts. In announcing the Paper Use Reduction Campaign, the BSC President and General Manager stated, "The Project has made 15 million copies to date (August 2001) this fiscal year. Clearly we are using too much paper on this Project, and I have set an aggressive goal of reducing paper use by 50 percent."

Management Program: To achieve this goal and target, several methods are being used:

- $\quad$ reducing the number of copies made,

- $\quad$ using double-sided copying,

- $\quad$ printing only what you need,

- $\quad$ using the BSC Reproduction Department for larger copying jobs,

- reducing the number of meeting handouts,

- $\quad$ sending electronic copies instead of hard copies, and

- reducing correspondence "cc's and bcc's" to only those with a need to know.

A Waste Minimization and Pollution Prevention Awareness poster entitled "Don't Be A Copy Hog" was posted above the photocopiers in each BSC building. This poster emphasizes the concepts of the Paper Use Reduction Campaign and reminds us to do our part. In announcing the paper use reduction campaign (BSC Today, August 2001), the BSC President and General Manager stated that he "Expected all BSC employees to actively participate in reducing the amount of paper use, and subsequent paper waste, during the course of our daily work." Additional guidelines from BSC's President and General Manager were published on June 11, 2002 in the BSC Today employee communication database. Paper purchases and use are being tracked. 


\subsection{Objective \# 4: Have No Notices of Violation (NOVs) for Any Environmental Permit, State or Federal Law, or Regulation.}

The YMP must comply with the requirements of numerous state and federal environmental laws, Departmental Orders, and stipulations in various State and Federal environmental permits and right-of-way reservations. The objective is to ensure no violations of any of these requirements. The specific targets for compliance are specified in permits, right-of-way reservations, laws, and regulations. Those targets are not repeated here but may be found in YMP records and readily available copies of state and federal laws and regulations.

Background: The YMP has had a longstanding goal of no Notice's of Violations for environmental permits, state or federal laws, or regulations. The YMP Environmental Policy Statement states, "The YMSCO is firmly committed to ensuring incorporation of all departmental and national environmental protection goals in the daily conduct of our business. We (i.e., DOE and contractors) have an equal commitment to advance the goals of restoring and enhancing environmental quality and ensuring compliance with the letter and spirit of applicable environmental statutes, regulations, and standards." Consistent with the YMP Environmental Policy, BSC's Environmental Management Policy states, "It is the policy of BSC to conduct its operations in such a manner that neither production goals nor financial objectives shall excuse noncompliance and that we will: Comply with all applicable laws, regulations, and permits...".

Management Program: The YMP has an extensive environmental management program, that BSC manages and operates for DOE, for ensuring that the project complies with all applicable environmental laws, regulations, and permits (YMP/93-04). Numerous plans and procedures have been developed to ensure compliance. These plans and procedures can be found on the OCRWM Program Documents database on Lotus Notes. Evidence of compliance can be found in numerous monitoring, assessment, surveillance, and inspection reports.

\section{REFERENCES}

\subsection{Documents}

BAB000000-01717-4600-000009, Spill Prevention, Control, and Countermeasures Plan for Site Activities, Rev 1.

BA0000000-01717-3500-000003, ESF Sanitary Sewer System Operation and Maintenance Manual, Rev 1.

BA0000000-01717-3500-000005, Potable Water System Operations and Maintenance Manual, Rev 2.

TDR-CRW-SE-000008, Safety Basis Report, Rev 0, ICN 1.

US Fish and Wildlife Service, File No. 1-5-96-F-307R, Final Biological Opinion for Reinitiation of Formal Consultation for Yucca Mountain Site Characterization Studies. 
YMP/94-08, Stormwater Pollution Prevention Plan, Rev 6.

YMP/93-04, Environmental Management Plan, Rev 4.

\subsection{Procedures}

AP-2.17Q, Rev 1, Tracers, Fluids, and Materials Data Reporting and Management

AP-3.13Q, Rev 3, Design Control

AP-EM-002, Rev 1, Land Access and Environmental Compliance

AP-EM-004, Rev 0, BSCN 1, Spill Management

AP-EM-005, Rev 1, Environmental Media Sampling

AP-EM-006, Rev 0, Waste Management

AP-EM-007, Rev 0, Hazardous Material Approval and Tracking

AP-ESH-010, Rev 0, ES\&H Compliance Surveillances and Reporting

AP-REG-008, Rev 1, Transportation Management

AP-RP-002, Rev 1, BSCN 1, Radiological Work Permit (RWP) - Authorization for the Use of Radioactive Sources/Materials or Radiation Producing Equipment

AP-RP-003, Rev 0, BSCN 1, Radioactive Source/Material Control and Accountability

LP-4.5Q-BSC, Rev 1, Processing Purchase Requisitions and Procurement Documents

LP-AQ-001-M\&O, Rev 0, BSCN 1, Routine Operations and Maintenance for Ambient Particulate Matter Sampling

LP-AQ-003-M\&O, Rev 0, BSCN 1, Visible Emissions Observations

LP-CON-006Q-BSC, Rev 1, ICN 1, Receipt, Storage, Monitoring, and Issuance of Items

LP-ES-001-BSC, Rev 0, BSCN 1, Final Reclamation

LP-EM-001Q-BSC, Rev 0, Release, Readiness, Cleanup and Reporting

LP-ESH-003-BSC, Rev 0, ICN 2, Hot Work Permit for Welding, Cutting, and Brazing

LP-ESH-012-BSC, Rev 1, ICN 1, Hazard Communications

LP-ESH-037-BSC, Rev 0, Emergency Preparedness and Response

LP-ESH-037-BSC, Rev 0, Potable Water System Operations and Maintenance 
LP-OM-040Q-BSC, Rev 0, ICN 1, Tracers, Fluids, and Materials Estimating, Accounting, and Reporting

LP-OM-049-BSC, Rev 0, ESF Sanitary Sewer System Operation and Maintenance

LP-OM-057Q-BSC, Rev 0, Diesel-Powered Equipment Emissions Testing and Control Procedure

LP-QC-003-BSC, Rev 1, Potable Water System Chlorine Residual Measurement

LP-RP-001-M\&O, Rev 1, BSCN 1, Handheld Radiation Survey Meter Calibration, Source Response Check, and Operation

LP-TM-001-BSC, Rev 0, Hazardous Material Off-Site Shipment Verification

NWI-ESF-037, Rev 0, BSCN 1, Procedure for Freon/Refrigerant Control

PRO-FB-003, Rev 0, BSCN 1, High-Risk Property Procedure

SO-2002-01, Rev 0, Dust Control and Water Conservation Plan

\subsection{Permits}

Air Quality Operating Permit, AP9199-0573.01 issued by Nevada Department of Environmental Protection, Bureau of Air Quality

Final Biological Opinion for Reinitiation of Formal Consultation for Yucca Mountain Site Characterization Studies, File No. 1-5-96-F-307R issued by the U.S. Fish and wildlife Service

Free Use Permits N51530, N55574, 63370 issued by the U.S. Bureau of Land Management

General Discharge Permit (Stormwater), GNV0022241-30054 UNEV89031 issued by Nevada Department of Environmental Protection

Groundwater Appropriation Permits for Well J-13 (57374, 57376) and Well J-12 (57373) issued by Nevada State Engineer

Hazardous Material Storage Permit, 13-99-0073-X issued by Nevada State Fire Marshall

Land Withdrawal, PLO6802, issued by U.S. Bureau of Land Management

Public Water System Permit, NY-0867-12NCNT issued by Nevada Department of Health

RCRA EPA Registration and ID Number NV7890090023 issued by Nevada Department of Environmental Protection

Right-Of-Way Reservations, N-48602 and N-47748 issued by U.S. Bureau of Land Management and U.S. Air Force. 
Scientific Collection Permit S 21678 issued by Nevada Division of Wildlife

Septic Tank General Discharge Permit, GNEV9201-40037 UNEV89031 issued by Nevada Department of Environmental Protection

Underground Injection Control Permit UNEV89031 issued by Nevada Department of Environmental Protection, Bureau of Water Pollution Control 


\section{APPENDICES}




\section{Appendix A}

Table A.1. Description of Potential Environmental Impacts Associated with BSC Environmental Aspects

\begin{tabular}{|c|c|c|c|}
\hline $\begin{array}{l}\text { Environmental } \\
\text { Aspect }\end{array}$ & Potential Environmental Impact & Supporting Information & Controls \\
\hline Air Emissions & Deterioration of air quality & $\begin{array}{l}\text { Operation of vehicles and heavy equipment may create fugitive dust } \\
\text { and release gaseous emissions such as } \mathrm{CO}_{x}, \mathrm{SO}_{x} \text {, and } \mathrm{NO}_{\mathrm{x}} \text {. }\end{array}$ & $\begin{array}{l}\text { Air Quality Operating } \\
\text { Permit, AP9199-0573 } \\
\text { AP-ESH-010 } \\
\text { LP-AQ-003-M\&O } \\
\text { LP-AQ-001-M\&O } \\
\text { LP-OM-057Q-BSC }\end{array}$ \\
\hline $\begin{array}{l}\text { Ozone depleting } \\
\text { substance use (ODS) }\end{array}$ & Loss of atmospheric ozone & $\begin{array}{l}\text { The project still operates some equipment that uses freon/refrigerants. } \\
\text { These are considered ODSs. No new equipment with Class I ODSs } \\
\text { may be purchased or used on the project. }\end{array}$ & $\begin{array}{l}\text { LP-4.5Q-BSC } \\
\text { NWI-ESF-037 }\end{array}$ \\
\hline Land Disturbance & $\begin{array}{l}\text { Loss of wildlife habitat, soil (i.e., } \\
\text { erosion) \& plants, mortality of } \\
\text { animals, destruction of cultural } \\
\text { resources, and alteration of surface } \\
\text { hydrology }\end{array}$ & $\begin{array}{l}\text { Land disturbance occurs during science and engineering studies that } \\
\text { require boreholes, trenches, or pits. Sites are typically cleared of all } \\
\text { vegetation. Similar disturbances are made during the construction of } \\
\text { facilities, installation of utilities, and development of borrow pits. }\end{array}$ & $\begin{array}{l}\text { AP-EM-002 } \\
\text { Biological Opinion } \\
\text { Right of Way } \\
\text { Reservations \& Free } \\
\text { Use permits } \\
\text { LP-ES-001-M\&O }\end{array}$ \\
\hline Facility Construction & $\begin{array}{l}\text { Loss of aesthetic value, creation of } \\
\text { wildlife habitat, mortality of animals, } \\
\text { consumption of natural resources in } \\
\text { building materials, generation of } \\
\text { waste material }\end{array}$ & $\begin{array}{l}\text { Facilities are constructed to support ongoing science and engineering } \\
\text { studies at Yucca Mountain. Facilities may become new habitat for } \\
\text { some wildlife species and also may cause wildlife mortality. Facility } \\
\text { construction requires the consumption of various building materials } \\
\text { that come from both renewable and nonrenewable sources. }\end{array}$ & $\begin{array}{l}\text { AP-3.13Q } \\
\text { AP-ESH-010 }\end{array}$ \\
\hline Electricity Use & $\begin{array}{l}\text { Consumption of non-renewable } \\
\text { natural resources }\end{array}$ & $\begin{array}{l}\text { Electrical power is used at all BSC facilities. This power usage } \\
\text { contributes to consumption of non-renewable resources used in power } \\
\text { generation }\end{array}$ & None \\
\hline
\end{tabular}


Table A.1. Description of Potential Environmental Impacts Associated with BSC Environmental Aspects

\begin{tabular}{|c|c|c|c|}
\hline $\begin{array}{l}\text { Environmental } \\
\text { Aspect }\end{array}$ & Potential Environmental Impact & Supporting Information & Controls \\
\hline $\begin{array}{l}\text { Petroleum product } \\
\text { use }\end{array}$ & $\begin{array}{l}\text { Consumption of non-renewable } \\
\text { natural resources }\end{array}$ & $\begin{array}{l}\text { BSC operates a variety of light duty vehicles and heavy equipment to } \\
\text { perform work at Yucca Mountain. These vehicles are fueled at the } \\
\text { site. Heavy equipment is serviced (i.e., oil and lubricants) at the site. } \\
\text { However, light duty vehicles are serviced off-site. A fleet of light duty } \\
\text { vehicles (vans and sedans) for transportation between facility locations } \\
\text { is operated and maintained out of the Summerlin campus. The GSA } \\
\text { vehicle fleet based in Las Vegas is serviced off-site in commercial } \\
\text { service and repair shops. These vehicles and equipment consume } \\
\text { petroleum-based fuels and lubricants. The YMP also provides } \\
\text { commuter bus service to those workers permanently stationed at } \\
\text { Yucca Mountain. }\end{array}$ & $\begin{array}{l}\text { No controls for } \\
\text { petroleum product Use } \\
\text { by light duty vehicles or } \\
\text { heavy equipment } \\
\text { Bus Service provided to } \\
\text { Yucca Mountain }\end{array}$ \\
\hline Potable Water Use & Depletion of groundwater supply & $\begin{array}{l}\text { All BSC facilities require and use potable water for drinking water and } \\
\text { sanitary utilities. All facilities except Yucca Mountain are connected to } \\
\text { municipal water and sewer systems. At Yucca Mountain, potable } \\
\text { water is pumped from Wells J- } 12 \text { and } 13 \text { and treated with chlorine in a } \\
\text { project constructed and State regulated water system. This water is } \\
\text { used for showers and restrooms. Drinking water at all facilities is } \\
\text { generally delivered through purchased bottled water. Waste potable } \\
\text { water is discharged through a project constructed and State permitted } \\
\text { septic system. }\end{array}$ & $\begin{array}{l}\text { Public Water System } \\
\text { Permit NY-0867- } \\
\text { 12NCNT } \\
\text { various Water } \\
\text { Appropriation Permits } \\
\text { Potable Water System } \\
\text { Operations \& } \\
\text { Maintenance Manual } \\
\text { AP-EM-005 } \\
\text { LP-OM-029-BSC } \\
\text { LP-QC-003-BSC }\end{array}$ \\
\hline $\begin{array}{l}\text { Non-potable Water } \\
\text { Use }\end{array}$ & Depletion of groundwater supply & $\begin{array}{l}\text { Non-potable water is used at the Yucca Mountain for fire suppression, } \\
\text { dust control, in the ESF tunnel to support testing studies, and surface } \\
\text { testing studies. Non-potable water is pumped from primarily for Well } \\
\mathrm{J}-12,13 \text {, and VH-1. }\end{array}$ & $\begin{array}{l}\text { Various Water } \\
\text { Appropriation Permits } \\
\text { SO-2002-01 }\end{array}$ \\
\hline Water Runoff & $\begin{array}{l}\text { Soil erosion, surface water } \\
\text { contamination, }\end{array}$ & $\begin{array}{l}\text { Construction of facilities, roads, and other land disturbances at Yucca } \\
\text { Mountain may increase the amount of surface water runoff and the } \\
\text { potential for contamination of runoff waters. The project operates } \\
\text { under a General Discharge Permit that allows discharge of stormwater } \\
\text { from construction sites larger than } 5 \text { acres. Runoff associated with } \\
\text { leased facilities in urban environments is not the responsibility or } \\
\text { under the control of BSC. }\end{array}$ & $\begin{array}{l}\text { General Discharge } \\
\text { Permit GNV0022241- } \\
30054 \\
\text { Storm Water Pollution } \\
\text { Prevention Plan }\end{array}$ \\
\hline
\end{tabular}


Table A.1. Description of Potential Environmental Impacts Associated with BSC Environmental Aspects

\begin{tabular}{|c|c|c|c|}
\hline $\begin{array}{l}\text { Environmental } \\
\text { Aspect }\end{array}$ & Potential Environmental Impact & Supporting Information & Controls \\
\hline Paper use & $\begin{array}{l}\text { Consumption of renewable } \\
\text { resource, waste generation }\end{array}$ & $\begin{array}{l}\text { A primary product of BSC work is documentation of science, } \\
\text { engineering, administration, and management work conducted for the } \\
\text { YMP. Much of this documentation occurs in the form of hardcopy } \\
\text { (paper). Therefore paper is a major input into BSC work activities. }\end{array}$ & $\begin{array}{l}\text { BSC General Manager } \\
\text { established } 50 \% \text { Paper } \\
\text { Use Reduction objective } \\
\& \text { target }\end{array}$ \\
\hline Wildfire & $\begin{array}{l}\text { Loss of wildlife habitat, plants, and } \\
\text { increased soil erosion }\end{array}$ & $\begin{array}{l}\text { Because the work at Yucca Mountain occurs in an undeveloped desert } \\
\text { environment, work activities such as operating equipment (such as } \\
\text { welders), vehicles, or any activity that has a heat source could } \\
\text { potentially cause a wildfire. The desert ecosystem surrounding Yucca } \\
\text { Mountain is not fire adapted and therefore recovery from wildfire can } \\
\text { take many years. }\end{array}$ & $\begin{array}{l}\text { AP-EM-002 } \\
\text { LP-ESH-003-BSC } \\
\text { LP-ESH-037-BSC }\end{array}$ \\
\hline Off-road driving & $\begin{array}{l}\text { Wildlife mortality, destruction of } \\
\text { wildlife habitat, plants, increases soil } \\
\text { erosion, destruction of cultural } \\
\text { resources }\end{array}$ & $\begin{array}{l}\text { Because work at Yucca Mountain occurs in a remote desert } \\
\text { environment, off-road driving has the potential impact the environment } \\
\text { through increased soil erosion, destroying vegetation, or killing wildlife. }\end{array}$ & $\begin{array}{l}\text { AP-EM-002 } \\
\text { Biological Opinion }\end{array}$ \\
\hline $\begin{array}{l}\text { Underground tracer } \\
\text { injections }\end{array}$ & $\begin{array}{l}\text { Chemical contamination of rock and } \\
\text { groundwater }\end{array}$ & $\begin{array}{l}\text { Scientific and engineering studies being conducted at Yucca Mountain } \\
\text { use chemical tracers to study movements of water or gases through } \\
\text { geologic media. }\end{array}$ & $\begin{array}{l}\text { Underground Injection } \\
\text { Control Permit } \\
\text { UNEV89031 } \\
\text { AP-2.17Q } \\
\text { LP-OM-040Q-BSC }\end{array}$ \\
\hline $\begin{array}{l}\text { Spills (petroleum } \\
\text { products, chemicals) }\end{array}$ & $\begin{array}{l}\text { Contamination of soil, surface water, } \\
\text { release of volatile compounds into } \\
\text { the air }\end{array}$ & $\begin{array}{l}\text { Use of chemicals and petroleum-based products creates the potential } \\
\text { for accidental spills and leaks from equipment. This potential is } \\
\text { greatest at the Yucca Mountain. }\end{array}$ & $\begin{array}{l}\text { AP-EM-004 } \\
\text { AP-EM-006 } \\
\text { LP-EM-001Q-BSC }\end{array}$ \\
\hline $\begin{array}{l}\text { Hazardous Waste } \\
\text { Generation }\end{array}$ & $\begin{array}{l}\text { Contamination of soil \& water, } \\
\text { depletion of landfill space }\end{array}$ & $\begin{array}{l}\text { Various activities at all YMP facilities generate hazardous waste as } \\
\text { defined by } 42 \text { USC } 6901 \text { et seq. However, the volume is greatest at } \\
\text { the Yucca Mountain site. Hazardous waste generation creates the } \\
\text { possibility of contamination of soil and water. }\end{array}$ & $\begin{array}{l}\text { RCRA EPA Registration } \\
\text { \& ID \#NV7890090023 } \\
\text { AP-EM-006 } \\
\text { AP-REG-008 }\end{array}$ \\
\hline $\begin{array}{l}\text { Non-hazardous } \\
\text { Waste Generation }\end{array}$ & Depletion of landfill space & $\begin{array}{l}\text { Non-hazardous wastes consist of various types of waste that include } \\
\text { industrial, refuse, salvageable, and tires. These wastes are sent } \\
\text { offsite to either landfills or disposal facilities for recycling }\end{array}$ & AP-EM-006 \\
\hline
\end{tabular}


Table A.1. Description of Potential Environmental Impacts Associated with BSC Environmental Aspects

\begin{tabular}{|c|c|c|c|}
\hline $\begin{array}{l}\text { Environmental } \\
\text { Aspect }\end{array}$ & Potential Environmental Impact & Supporting Information & Controls \\
\hline $\begin{array}{l}\text { Hazardous Material } \\
\text { Use, Storage, and } \\
\text { Transportation }\end{array}$ & $\begin{array}{l}\text { Contamination of soil, water, air; } \\
\text { wildlife mortality }\end{array}$ & $\begin{array}{l}\text { Various project activities require the use of hazardous materials. Prior } \\
\text { to use these materials are also stored on-site. The use, storage, and } \\
\text { transportation may potentially cause contamination to soil, water, or air } \\
\text { and wildlife mortality if incorrectly handled, stored or released during } \\
\text { an abnormal event such as a fire or vehicle accident. Hazardous } \\
\text { waste materials also are stored in accumulation areas prior to } \\
\text { disposal. }\end{array}$ & $\begin{array}{l}\text { Hazardous Materials } \\
\text { Storage Permit 13-99- } \\
0073-X \\
\text { AP-EM-007 } \\
\text { LP-TM-001-BSC } \\
\text { AP-EM-006 } \\
\text { LP-ESH-012-BSC }\end{array}$ \\
\hline $\begin{array}{l}\text { Interaction with } \\
\text { Wildlife \& Habitat }\end{array}$ & $\begin{array}{l}\text { Mortality of wildlife, creation of } \\
\text { wildlife habitat or resources }\end{array}$ & $\begin{array}{l}\text { Activities located in relatively undisturbed desert ecosystems such as } \\
\text { Yucca Mountain creates a variety of ways by which BSC workers } \\
\text { and/or BSC facilities may directly interact with wildlife. Facilities may } \\
\text { become attractive habitats for a variety of animals that then occupy the } \\
\text { same areas where employees are working. Direct mortality of wildlife } \\
\text { may occur through vehicle collisions or from various facility structures } \\
\text { (e.g., ventilation fans). }\end{array}$ & $\begin{array}{l}\text { Biological Opinion \#1-5- } \\
\text { 96-F-307R } \\
\text { Site Access Training } \\
\text { Nevada Scientific \& } \\
\text { Animal Handling Permit }\end{array}$ \\
\hline Effluent Discharge & $\begin{array}{l}\text { Soil contamination, contamination of } \\
\text { surface water }\end{array}$ & $\begin{array}{l}\text { BSC operates a sanitary sewer system at the ESF North Portal Pad } \\
\text { that consists of the septic tank, the dosing tank, and the distribution } \\
\text { boxes and leach field piping. Improper operation may result in effluent } \\
\text { discharge to the soil. }\end{array}$ & $\begin{array}{l}\text { Septic Tank General } \\
\text { Discharge Permit } \\
\text { GNEV9201-40037 } \\
\text { LP-OM-049-BSC } \\
\text { Sanitary Sewer System } \\
\text { Operations and } \\
\text { Maintenance Manual }\end{array}$ \\
\hline Noise & Disturbance of wildlife & $\begin{array}{l}\text { Operation of facilities and equipment at Yucca Mountain may generate } \\
\text { noise that may be disruptive to wildlife. }\end{array}$ & None \\
\hline $\begin{array}{l}\text { Material \& equipment } \\
\text { storage }\end{array}$ & $\begin{array}{l}\text { Creation of wildlife habitat, soil } \\
\text { contamination, loss of aesthetics }\end{array}$ & $\begin{array}{l}\text { Storage of materials and equipment at Yucca Mountain may create } \\
\text { wildlife habitat, potential soil contamination from leaks, and loss of } \\
\text { aesthetics }\end{array}$ & $\begin{array}{l}\text { PRO-FB-003 } \\
\text { LP-CON-006Q-BSC }\end{array}$ \\
\hline Radiation exposure & $\begin{array}{l}\text { Sickness or other health effects from } \\
\text { exposure radiation }\end{array}$ & $\begin{array}{l}\text { Some scientific investigations conducted at Yucca Mountain use } \\
\text { radioactive sources. Improper use could expose human and non- } \\
\text { humans to radiation. }\end{array}$ & $\begin{array}{l}\text { AP-RP-002 } \\
\text { AP-RP-003 } \\
\text { LP-RP-001-M\&O }\end{array}$ \\
\hline
\end{tabular}




\section{Appendix B}

Table B.1. Description and Definition of Environmental Criteria for Evaluating the Significance of Environmental Aspects of BSC Activities, Products, and Services

\begin{tabular}{|l|l|l|l|}
\hline \multicolumn{4}{|c|}{ Environmental Considerations } \\
\hline $\begin{array}{l}\text { Definition: Environmental considerations involve potential impacts to air, water, flora, fauna, soil, and other } \\
\text { renewable and non-renewable natural resources. In evaluating potential environmental impacts for } \\
\text { significance, several characterizations of the impact are considered. These include scale (or magnitude), } \\
\text { severity, frequency of occurrence, and duration of the impact. }\end{array}$ \\
\hline Impact Characteristic & \multicolumn{1}{|c|}{ High (H) } & \multicolumn{1}{c|}{ Medium (M) } & \multicolumn{1}{c|}{ Low (L) } \\
\hline Scale & $\begin{array}{l}\text { Large, spread beyond } \\
\text { facility boundary }\end{array}$ & $\begin{array}{l}\text { Limited to inside facility } \\
\text { boundary }\end{array}$ & $\begin{array}{l}\text { Small relative to size of } \\
\text { facility }\end{array}$ \\
\hline Severity & $\begin{array}{l}\text { Permanent impact or } \\
\text { extension effort required } \\
\text { to reverse change }\end{array}$ & $\begin{array}{l}\text { Short-term impacts that } \\
\text { are fully recoverable given } \\
\text { remediation or time }\end{array}$ & $\begin{array}{l}\text { Minor changes that are } \\
\text { relatively non-discernible }\end{array}$ \\
\hline $\begin{array}{l}\text { Frequency of } \\
\text { Occurrence }\end{array}$ & $\begin{array}{l}\text { Once or more/year } \\
1 \text { in 3 years }\end{array}$ & $<1$ in 3 years \\
\hline Duration & $\begin{array}{l}\text { Long-term change, }>5 \\
\text { years to remediate }\end{array}$ & $3-5$ years to remediate & $<=2$ years to remediate \\
\hline
\end{tabular}

Table B.2. Description and Definition of Safety and Health Criteria for Evaluating the Significance of Environmental Aspects of BSC Activities, Products, and Services.

\section{Safety and Health Considerations}

Definition: Safety and Health considerations account for consequences of environmental aspects as they affect the safety and health of BSC employees, subcontractors, and the general public. Considerations include severity of the occurrence.

\begin{tabular}{|l|l|l|l|}
\hline Impact Characteristic & \multicolumn{1}{|c|}{ High (H) } & \multicolumn{1}{c|}{ Medium (M) } & \multicolumn{1}{c|}{ Low (L) } \\
\hline Severity & $\begin{array}{l}\text { Multiple serious injuries, } \\
\text { acute health impact, } \\
\text { fatalities, or minor, } \\
\text { widespread health } \\
\text { hazard }\end{array}$ & $\begin{array}{l}\text { Serious injury, or minor, } \\
\text { localized health impact }\end{array}$ & $\begin{array}{l}\text { Minor injuries or health } \\
\text { impact, limited lost-time } \\
\text { injuries }\end{array}$ \\
\hline
\end{tabular}

Table B.3. Description and Definition of Regulatory Compliance Criteria for Evaluating the Significance of Environmental Aspects of BSC Activities, Products, and Services.

\section{Regulatory Compliance}

Definition: Regulatory compliance considers the consequences of laws, regulations, and other statues on environmental aspects. Considerations include the potential regulatory response and extent of agency oversight.

\begin{tabular}{|l|l|l|l|}
\hline $\begin{array}{l}\text { Impact } \\
\text { Characteristic }\end{array}$ & \multicolumn{1}{|c|}{ High (H) } & \multicolumn{1}{c|}{ Medium (M) } & \multicolumn{1}{c|}{ Low (L) } \\
\hline Regulatory Response & $\begin{array}{l}\text { Likely to result in significant } \\
\text { and visible regulatory } \\
\text { action, and significant fines } \\
\text { and penalties }\end{array}$ & $\begin{array}{l}\text { Moderate potential for } \\
\text { NOVs, fines, or penalties }\end{array}$ & $\begin{array}{l}\text { Very low potential for } \\
\text { NOVs, fines, or penalties }\end{array}$ \\
\hline Agency oversight & $\begin{array}{l}\text { Subject to major scrutiny by } \\
\text { regulatory agencies } \\
\text { through inspections }\end{array}$ & $\begin{array}{l}\text { Regulated, but not high } \\
\text { profile issue. }\end{array}$ & $\begin{array}{l}\text { Not regulated or } \\
\text { regulated but of little } \\
\text { agency concern }\end{array}$ \\
\hline
\end{tabular}


Table B.4. Description and Definition of Financial Criteria for Evaluating the Significance of Environmental Aspects of BSC Activities, Products, and Services

\begin{tabular}{|c|c|c|c|}
\hline \multicolumn{4}{|c|}{ Financial Considerations } \\
\hline \multicolumn{4}{|c|}{$\begin{array}{l}\text { Definition: Financial considerations account for the cost associated with an environmental aspect. The cost } \\
\text { may be from procuring an environmental aspect such as electrical energy or from rectifying an } \\
\text { environmental impact through cleanup, remediation, or reclamation. }\end{array}$} \\
\hline Impact Characteristic & High $(H)$ & Medium (M) & Low (L) \\
\hline Cost to business & $\begin{array}{l}\text { Relatively large cost, } \\
>\$ 100 \mathrm{~K} / \mathrm{yr}, \text { potential for } \\
\text { significant cost savings }\end{array}$ & $\begin{array}{l}\text { Moderate cost to } \\
\text { business, } \$ 10-100 \\
\text { K/yr., potential for cost } \\
\text { savings }\end{array}$ & $\begin{array}{l}\text { Minor cost to business, } \\
<\$ 10 \mathrm{~K} / \mathrm{yr} \text {. }\end{array}$ \\
\hline Cost for remedial action & $\begin{array}{l}\text { Significant cost for } \\
\text { remediation, repair or } \\
\text { replacement of facilities } \\
\text { and equipment, } \\
>\$ 100 \mathrm{~K} / \mathrm{yr}\end{array}$ & $\begin{array}{l}\text { Moderate cost for } \\
\text { remedial action, } \\
\text { replacement or repair of } \\
\text { facilities or equipment, } \\
\$ 10-100 \mathrm{~K} / \mathrm{yr} \text {. }\end{array}$ & $\begin{array}{l}\text { Minor cost for remedial } \\
\text { action, }<\$ 10 \mathrm{~K} / \mathrm{yr} \text {. }\end{array}$ \\
\hline
\end{tabular}

Table B.5. Description and Definition of Business Criteria for Evaluating the Significance of Environmental Aspects of BSC Activities, Products, and Services

\begin{tabular}{|c|c|c|c|}
\hline \multicolumn{4}{|c|}{ Business Considerations } \\
\hline \multicolumn{4}{|c|}{$\begin{array}{l}\text { Definition: Business considerations involve judgement of whether an environmental aspect impacts other } \\
\text { company activities, affects the company's ability to conduct business, or impacts the company through } \\
\text { public image. }\end{array}$} \\
\hline Impact Characteristic & High (H) & Medium (M) & Low (L) \\
\hline $\begin{array}{l}\text { Impact on company } \\
\text { work activities }\end{array}$ & $\begin{array}{l}\text { May cause some work } \\
\text { activities to stop }>1 \text { day } \\
\text { or entire business } \\
\text { operations may have to } \\
\text { stop work } \geq 1 \text { day, } \\
\text { significant interruption to } \\
\text { business }\end{array}$ & $\begin{array}{l}\text { May cause some work } \\
\text { activities or business } \\
\text { units to stop }<1 \text { day, } \\
\text { minor interruption to } \\
\text { business }\end{array}$ & $\begin{array}{l}\text { No affect on other } \\
\text { activities }\end{array}$ \\
\hline $\begin{array}{l}\text { Effect on public image of } \\
\text { company }\end{array}$ & Newsworthy & $\begin{array}{l}\text { May generate some } \\
\text { public interest or } \\
\text { feedback }\end{array}$ & $\begin{array}{l}\text { Public not likely } \\
\text { interested }\end{array}$ \\
\hline
\end{tabular}




\section{Appendix C}

Table C.1. Significance ratings for BSC Environmental Aspects Based on Characteristic of the Potential Environmental Impact

\begin{tabular}{|c|c|c|c|c|c|}
\hline \multirow[b]{2}{*}{ Environmental Aspect } & \multicolumn{5}{|c|}{ Characteristic of Environmental Impact } \\
\hline & Scale & Severity & $\begin{array}{l}\text { Frequency of } \\
\text { Occurrence }\end{array}$ & Duration & Overall \\
\hline Air Emissions & Low & Low & High & Low & Low \\
\hline Ozone depleting substance use & Low & Low & Medium & Low & Low \\
\hline Land Disturbance & Low & High & High & High & High \\
\hline Facility Construction & Low & Medium & High & Medium & Low \\
\hline Electricity Use & Low & Low & High & Low & Low \\
\hline Petroleum product use & Low & Low & High & Low & Low \\
\hline Potable Water Use & Low & Low & Low & Low & Low \\
\hline Non-potable Water Use & Low & Low & Low & Low & Low \\
\hline Water Runoff & Low & Low & Medium & Low & Low \\
\hline Paper use & Medium & Medium & High & Medium & Medium \\
\hline Wildfire & Medium & Medium & Low & High & Medium \\
\hline Off-road driving & Medium & Medium & Medium & Medium & Medium \\
\hline Underground tracer injections & Low & Low & High & Low & Low \\
\hline $\begin{array}{l}\text { Spills (petroleum products, } \\
\text { chemicals) }\end{array}$ & Low & Low & Medium & Low & Low \\
\hline Hazardous Waste Generation & Low & Low & High & Low & Low \\
\hline $\begin{array}{l}\text { Non-hazardous Waste } \\
\text { Generation }\end{array}$ & Low & Low & High & Low & Low \\
\hline $\begin{array}{l}\text { Hazardous Material Use, } \\
\text { Storage, and Transportation }\end{array}$ & Low & Low & High & Low & Low \\
\hline Interaction with Wildlife \& Habitat & Low & Low & High & Low & Low \\
\hline Effluent Discharge & Low & Low & High & Low & Low \\
\hline Noise & Low & Low & High & Low & Low \\
\hline Material \& equipment storage & Low & Low & High & Low & Low \\
\hline Radiation exposure & Low & Low & Low & Low & Low \\
\hline
\end{tabular}


Table C.2. Significance Ratings for BSC Environmental Aspects Based on Safety and Health Factors

\begin{tabular}{|l|c|c|}
\hline & \multicolumn{2}{|c|}{ Safety and Health Factors } \\
\hline Environmental Aspect & Severity & Overall \\
\hline Air Emissions & Low & Low \\
\hline Ozone depleting substance use & Low & Low \\
\hline Land Disturbance & Low & Low \\
\hline Facility Construction & Low & Low \\
\hline Electricity Use & Low & Low \\
\hline Petroleum product use & Low & Low \\
\hline Potable Water Use & Low & Low \\
\hline Non-potable Water Use & Low & Low \\
\hline Water Runoff & Low & Low \\
\hline Paper use & Low & Low \\
\hline Wildfire & Medium & Medium \\
\hline Off-road driving & Low & Low \\
\hline Underground tracer injections & Low & Low \\
\hline Spills (petroleum products, chemicals) & Low & Low \\
\hline Hazardous Waste Generation & Low & Low \\
\hline Non-hazardous Waste Generation & Low & Low \\
\hline Hazardous Material Use, Storage, and & Low & Low \\
\hline Transportation & Low & Low \\
\hline Interaction with Wildlife \& Habitat & Low & Low \\
\hline Effluent Discharge & Low & Low \\
\hline Noise & Low & Medium \\
\hline Material \& equipment storage & & \\
\hline Radiation exposure & & \\
\hline
\end{tabular}


Table C.3. Significance Ratings for BSC Environmental Aspects Based on Regulatory Compliance Considerations

\begin{tabular}{|c|c|c|c|}
\hline \multirow[b]{2}{*}{ Environmental Aspect } & \multicolumn{3}{|c|}{ Regulatory Compliance Factors } \\
\hline & $\begin{array}{l}\text { Regulatory } \\
\text { Response }\end{array}$ & Agency Oversight & Overall \\
\hline Air Emissions & Medium & High & Medium \\
\hline Ozone depleting substance use & Low & Low & Low \\
\hline Land Disturbance & Low & Medium & Low \\
\hline Facility Construction & Low & Low & Low \\
\hline Electricity Use & Low & Low & Low \\
\hline Petroleum product use & Low & Low & Low \\
\hline Potable Water Use & Low & High & High \\
\hline Non-potable Water Use & Low & High & High \\
\hline Water Runoff & Low & Low & Low \\
\hline Paper use & Low & Low & Low \\
\hline Wildfire & Low & Low & Low \\
\hline Off-road driving & Low & Medium & Low \\
\hline Underground tracer injections & Medium & Medium & Medium \\
\hline Spills (petroleum products, chemicals) & Medium & Medium & Medium \\
\hline Hazardous Waste Generation & Low & Medium & Medium \\
\hline Non-hazardous Waste Generation & Low & Low & Low \\
\hline $\begin{array}{l}\text { Hazardous Material Use, Storage, and } \\
\text { Transportation }\end{array}$ & Low & Medium & Medium \\
\hline Interaction with Wildlife \& Habitat & Low & Low & Low \\
\hline Effluent Discharge & Low & Medium & Medium \\
\hline Noise & Low & Low & Low \\
\hline Material \& equipment storage & Low & Low & Low \\
\hline Radiation exposure & Low & Medium & Low \\
\hline
\end{tabular}


Table C.4. Significance Ratings for BSC Environmental Aspects Based on Financial Considerations

\begin{tabular}{|l|c|c|c|}
\hline & \multicolumn{3}{|c|}{ Financial Factors } \\
\hline Environmental Aspect & Cost to business & $\begin{array}{c}\text { Cost for Remedial } \\
\text { Action }\end{array}$ & Overall \\
\hline Air Emissions & Low & Low & Low \\
\hline Ozone depleting substance use & Low & Low & Low \\
\hline Land Disturbance & Medium & High & High \\
\hline Facility Construction & Low & Low & Low \\
\hline Electricity Use & Medium & Low & Medium \\
\hline Petroleum product use & Medium & Low & Medium \\
\hline Potable Water Use & Medium & Low & Medium \\
\hline Non-potable Water Use & Medium & Low & Medium \\
\hline Water Runoff & Low & Medium & Low \\
\hline Paper use & High & Low & High \\
\hline Wildfire & Medium & Medium & Medium \\
\hline Off-road driving & Low & Medium & Low \\
\hline Underground tracer injections & Low & Low & Low \\
\hline Spills (petroleum products, chemicals) & Low & Medium & Medium \\
\hline Hazardous Waste Generation & Medium & Low & Medium \\
\hline Non-hazardous Waste Generation & Low & Low & Low \\
\hline Hazardous Material Use, Storage, and & Low & Low & Low \\
\hline Transportation & Low & Low & Low \\
\hline Interaction with Wildlife \& Habitat & Low & Low & Low \\
\hline Effluent Discharge & Low & Low \\
\hline Noise & Low & Low \\
\hline Material \& equipment storage & Low & \multicolumn{2}{|c|}{} \\
\hline Radiation exposure & Low & \multicolumn{1}{|c|}{} \\
\hline
\end{tabular}


Table C.5. Significance Ratings for BSC Environmental Aspects Based on Business Operation Factors.

\begin{tabular}{|c|c|c|c|}
\hline \multirow[b]{2}{*}{ Environmental Aspect } & \multicolumn{3}{|c|}{ Business Factors } \\
\hline & $\begin{array}{l}\text { Impact on other } \\
\text { work activities }\end{array}$ & $\begin{array}{l}\text { Effect on public } \\
\text { image of company }\end{array}$ & Overall \\
\hline Air Emissions & Low & Medium & Medium \\
\hline Ozone depleting substance use & Low & Low & Low \\
\hline Land Disturbance & Low & Low & Low \\
\hline Facility Construction & Low & Low & Low \\
\hline Electricity Use & Medium & Low & Medium \\
\hline Petroleum product use & Low & Low & Low \\
\hline Potable Water Use & High & Medium & High \\
\hline Non-potable Water Use & High & Medium & High \\
\hline Water Runoff & Low & Low & Low \\
\hline Paper use & Low & Low & Low \\
\hline Wildfire & Medium & Low & Medium \\
\hline Off-road driving & Low & Low & Low \\
\hline Underground tracer injections & Low & Medium & Medium \\
\hline $\begin{array}{l}\text { Spills (petroleum products, } \\
\text { chemicals) }\end{array}$ & Low & Medium & Medium \\
\hline Hazardous Waste Generation & Low & Low & Low \\
\hline Non-hazardous Waste Generation & Low & Low & Low \\
\hline $\begin{array}{l}\text { Hazardous Material Use, Storage, } \\
\text { and Transportation }\end{array}$ & Medium & Medium & Medium \\
\hline Interaction with Wildlife \& Habitat & Low & Low & Low \\
\hline Effluent Discharge & Low & Low & Low \\
\hline Noise & Low & Low & Low \\
\hline Material \& equipment storage & Low & Low & Low \\
\hline Radiation exposure & Low & Medium & Medium \\
\hline
\end{tabular}

